\title{
Phytochemical, Cytotoxic, and Antimicrobial Evaluation of the Fruits of Miswak Plant, Salvadora persica $\mathbf{L}$.
}

\author{
Mohammed Al Bratty, ${ }^{1}$ Hafiz A. Makeen, ${ }^{2}$ Hassan A. Alhazmi, ${ }^{1,3}$ Sohier M. Syame, ${ }^{4,5}$ \\ Ashraf N. Abdalla, ${ }^{6,7}$ Husham E. Homeida, ${ }^{4}$ Shahnaz Sultana, ${ }^{8}$ Waquar Ahsan, ${ }^{1}$ \\ and Asaad Khalid $\mathbb{1 D}^{3,6}$ \\ ${ }^{1}$ Department of Pharmaceutical Chemistry, College of Pharmacy, Jazan University, P.O. Box 114, Jazan 45142, Saudi Arabia \\ ${ }^{2}$ Department Clinical Pharmacy, College of Pharmacy, Jazan University, P.O. Box 114, Jazan 45142, Saudi Arabia \\ ${ }^{3}$ Substance Abuse and Toxicology Research Centre, Jazan University, P.O. Box 114, Jazan 45142, Saudi Arabia \\ ${ }^{4}$ Faculty of Dentistry, Jazan University, P.O. Box 114, Jazan 54142, Saudi Arabia \\ ${ }^{5}$ Department of Microbiology and Immunology, National Research Centre, 33 Bohouth St. Dokki, Affiliation I.D. 60014618, \\ Giza 12311, Egypt \\ ${ }^{6}$ Medicinal and Aromatic Plants Research Institute, National Center for Research, P.O. Box 2424, Khartoum 11111, Sudan \\ ${ }^{7}$ Department of Pharmacology and Toxicology, Faculty of Pharmacy, Umm Al-Qura University, Makkah 21955, Saudi Arabia \\ ${ }^{8}$ Department of Pharmacognosy, College of Pharmacy, Jazan University, P.O. Box 114, Jazan 45142, Saudi Arabia
}

Correspondence should be addressed to Asaad Khalid; drasaad@gmail.com

Received 1 November 2019; Revised 25 April 2020; Accepted 5 May 2020; Published 29 May 2020

Academic Editor: Maria Grazia Perrone

Copyright ( 12020 Mohammed Al Bratty et al. This is an open access article distributed under the Creative Commons Attribution License, which permits unrestricted use, distribution, and reproduction in any medium, provided the original work is properly cited.

Salvadora persica L. (Salvadoraceae) is an evergreen shrub growing in the Middle East, Africa, and Southern Asia. It is traditionally known as "miswak" and used as toothbrushes and for the treatment of toothache, gum diseases, boils, chest infection, gonorrhea, headache, spleen troubles, stomachache, and ulcers. To the best of our knowledge, this is the first study aimed at conducting phytochemical, cytotoxic, and antimicrobial investigations of the fruits (berries) of $S$. persica collected from the Jazan region of Saudi Arabia. Analysis of the ethanol extract of S. persica fruits using GC-MS showed the presence of six esters (20.71\%), seven alkanes (15.47\%), tetracosamethyl-cyclododecasiloxane (9.91\%), eicosamethyl-cyclodecasiloxane (7.27\%), and 1-monolinoleoylglycerol (5.17\%). The predominant constituents were acetyl dasycarpidan-1-methanol (10.47\%), tetracosamethyl-cyclododecasiloxane (9.91\%), eicosamethyl-cyclodecasiloxane (7.27\%), and 1-monolinoleoylglycerol (5.17\%). The petroleum ether extract of the fruits contained mainly eicosamethyl-cyclodecasiloxane (23.81\%), 1-monolinoleoylglycerol (11.78\%), (Z,Z,Z)-9,12,15-octadecatrienoic acid ethyl ester derivative (10.56\%), and tetracosamethyl-cyclododecasiloxane (9.91\%). The cytotoxic properties of the ethanol extract were investigated by MTT assay against the breast MCF7, ovary A2780, and colon HT29 cells. The fruit extract of $S$. persica was selective against the ovarian and colon cancer cells compared to normal fibroblast cells (MRC5) as it showed IC $_{50}$ values 17.50, 8.35, and 5.12, against MCF7, A2780, and HT29 cells, respectively. Interestingly, the fruit extract was also found to possess selective antimicrobial activity for Streptococcus mutans isolates with minimum inhibitory concentration (MIC) and minimum bactericidal concentration (MBC) values of $3.12 \mathrm{and} 6.25 \mathrm{mg} / \mathrm{mL}$, respectively. Interestingly, it was found to be ineffective against other Gram-positive as well as Gram-negative microorganisms. This study provides insight into the bioactive components present in the fruits of the plant that can be utilized for its cytotoxic and antimicrobial properties. 


\section{Introduction}

Salvadora persica L. (family: Salvadoraceae), which has many local names (miswak, peelu, toothbrush tree, and mustard tree), is an ancient native plant found in Africa, Iran, Pakistan, India, Sri Lanka, and the Middle East countries including Saudi Arabia, Oman, Yemen, Jordan, and Syria $[1,2]$. It is an evergreen shrub with a wide crown of curved branches, slightly rough bark, greyish-brown stem, greenish-yellow flowers, and fleshy pink fruits [3].

There are many traditional uses reported for the $S$. persica plant. It has mainly been used in dental care to cure toothache and gum diseases and for cleaning teeth. Additionally, it is used to relieve boils, chest diseases, gonorrhea, headache, spleen troubles, stomachache, and ulcers. The root infusion can also be used to increase milk production in lactating women. Leaves of the plant are being utilized as a mouthwash and in treatment of chest pain, cough, tooth and gum problems, body pain, backache, piles, stomachache, stomatitis, and wounds. The bark latex is beneficial to subside skin sores. The seeds are taken as a tonic, and the seed oil is rubbed to treat joint pain, lumbago, and rheumatism. It has also been used to relieve edema, fever, malaria, and worms. The plant juice is used by women as a female contraceptive $[1,4]$.

The uses of stem and roots of $S$. persica in dentistry could be correlated to the presence of many phytochemical constituents such as tannins that inhibits glucosyltransferase enzyme to reduce plaque and gingivitis [5]. The resins of the chewing stick of the plant protect against dental caries by forming a layer on enamel [6]. Salvadorine isolated from the chewing stick of $S$. persica exerted bactericidal effects and stimulated the gingiva [7]. Recently, five $\alpha$-amylases were isolated from the roots of the plant which showed good affinity towards the substrates such as starch and glycogen [8]. Moreover, S. persica sticks were found to stimulate the saliva flow in humans owing to the mildly bitter taste of essential oils present in it, which act as a buffer. Additionally, high chloride concentrations inhibit the calculus formation and removes stains from the tooth surfaces [7, 9]. Moreover, the use of chewing sticks causes calcium saturation in human saliva leading to promotion in remineralization of tooth enamel [5].

The anticancer activity of $S$. persica was also investigated. In a previous study, $S$. persica aqueous root extract exhibited oral protective activity on the normal periodontal ligament fibroblast (PDL) cell lines, and notably it caused cytotoxicity on oral cancer cells: oral epithelial dysplasia (DOK) and oral squamous cell carcinoma (PE/CA-PJ15), all using the MTT assay [10]. The MTT assay was also used to investigate the cytotoxicity of $S$. persica sticks and bark extracts against HepG2, MCF7, A549, and HCT116 cancer cells. S. persica extracted with petroleum ether showed the highest cytotoxicity compared to the same plant extracted with aqueous alcohol, chloroform, and ethyl acetate. The petroleum ether extract yielded two triterpenes (ursolic and oleanolic acids) which showed $\mathrm{IC}_{50} 10.2-43.6 \mu \mathrm{g} /$ $\mathrm{mL}$ against the four cancer cell lines [11].

Studies related to the importance of $S$. persica fruits as nutraceutical are very scarce and less investigated [12]. The nutritional value of the $S$. persica fruits has been demonstrated by the presence of sugar metabolites, minerals, amino acids, vitamins (ascorbic acid and carotenoids), polyphenols, and flavonoids. Previously, these metabolites were proved to have considerable antimicrobial, antihyperglycemic, antitumor, and antioxidant properties. The fermented fruit juice is a general body tonic and acts as strong aphrodisiac [12-14].

In spite of the ethnopharmacological importance of $S$. persica, the research on this plant has been focusing only on the stem and root of the plant. To the best of our knowledge, this is the first study to emphasize the cytotoxicity and antimicrobial properties of the fruits of $S$. persica. This study was conducted to identify the constituents of the plant using GC-MS. The cytotoxic and antimicrobial properties of the fruit extract of $S$. persica were evaluated keeping in mind the high reputation and traditional ethnopharmacological uses of the stem and roots of the plant.

\section{Materials and Methods}

2.1. Plant Collection and Extraction. Reddish purple fruits of S. persica were collected from Jazan region of Saudi Arabia in March 2018 and were identified by Dr. Yahiya Masrahi, Botany Department, Faculty of Science, Jazan University, Saudi Arabia. A voucher with specimen no. JU/COP/18-2 was deposited in the herbarium of the Department.

The fruits of $S$. persica were extracted using previously described method by Harborne [15] with some modifications. Fresh fruits of S. persica ( $500 \mathrm{~g})$ were grinded, macerated, and dipped in 2.5 liters of $80 \%$ ethanol and petroleum ether separately for $48 \mathrm{~h}$ at room temperature with constant shaking. The supernatant obtained was filtered using Whatman filter paper $(0.45 \mu \mathrm{m})$. This process was repeated two times in the same conditions. Both extracts were mixed and dried at room temperature. The dry weight yield was calculated to be $10 \%$. The extracts were then refrigerated at $4^{\circ} \mathrm{C}$ in dark bottles for consequent experiments.

2.2. GC-MS Analysis of the Extract. The extract was diluted in methanol $(1: 10 v / v)$ and was analyzed using Thermo Scientific GC-MS equipped with AS 3000 autosampler, Trace GC ultra, and ISQ detector. Thermo Scientific TR 5MS with dimensions of $30 \mathrm{~m} \times 0.25 \mathrm{~mm}$ (internal diameter) $\times 0.25 \mu \mathrm{m}$ (film thickness) was used for separation of the components. Helium, at a flow rate of $1.2 \mathrm{~mL} / \mathrm{min}$ (constant flow mode), was used as carrier gas. A volume of $2 \mu \mathrm{L}$ of sample extracts was injected in splitless mode. The injection port was set at $320^{\circ} \mathrm{C}$ and temperature of oven was initially set at $70^{\circ} \mathrm{C}$ for 5 minutes, which was subsequently ramped to $205^{\circ} \mathrm{C}$ at rate of $5^{\circ} \mathrm{C} / \mathrm{min}$ and held for 5 minutes, then increased to $280^{\circ} \mathrm{C}$ at rate of $5^{\circ} \mathrm{C} / \mathrm{min}$ and held for 5 minutes, then to $290^{\circ} \mathrm{C}$ at rate of $5^{\circ} \mathrm{C} / \mathrm{min}$ and again held for 5 minutes, and finally to $300^{\circ} \mathrm{C}$ at rate of $5^{\circ} \mathrm{C} / \mathrm{min}$ and held for 5 minutes. The maximum oven temperature was set at $320^{\circ} \mathrm{C}$. The mass spectrometer was operated in an electron ionization (EI) mode within the mass range of 60-900 amu with 0.6 scan times (min). The MS ion source temperature and transfer line temperature were set at $320^{\circ} \mathrm{C}$ and $350^{\circ} \mathrm{C}$, respectively, with electron multiplier voltage of $1 \mathrm{Kv}$. 
2.3. Identification of Phytochemical Constituents. The mass spectra were interpreted using Xcalibur software, and the fragmentation patterns in the mass spectra obtained for all constituents were compared with the data stored in the instrument database using the NIST, MAINLIB, and REPLIB built-in libraries. The constituent percentages were measured based on the peak area. The components were identified upon comparison with the structures available in the computer library. The reported biological activities of the constituents listed (Tables 1 and 2) are taken from Dr. Duke's Phytochemical and Ethnobotanical Databases [16].

2.4. Cytotoxicity Assay. Three cancer cell lines, MCF7 (human breast carcinoma cells), A2780 (human ovary carcinoma cells), and HT29 (human colon carcinoma cells), were used in this study to evaluate the cytotoxic properties of the fruit ethanol extract in addition to the effects on MRC5 (normal human fibroblast) cells. The three tumor cell lines were subcultured in RPMI-1640 media (prepared in 10\% Fetal Bovine Serum (FBS)), whereas MRC5 was subcultured in Eagle's Minimum Essential Medium (EMEM) (in 10\% FBS at $37^{\circ} \mathrm{C}$ temperature, $5 \% \mathrm{CO}_{2}$, and $100 \%$ relative humidity). The cytotoxic properties of the ethanol extract were evaluated using 3-(4,5-dimethylthiazol-2-yl)-2,5-diphenyl tetrazolium bromide (MTT) assay according to previous report $[17,18]$. The three cancer cell lines as well as the normal human fibroblast were cultured separately in 96-well $\left(3 \times 10^{3} /\right.$ well $)$ plates and placed for incubation at $37^{\circ} \mathrm{C}$ overnight. Thereafter, the final extract concentrations $0-100 \mu \mathrm{g} / \mathrm{mL}$ were prepared and added in triplicate to the wells. Plates were then incubated again for $72 \mathrm{~h}$, followed by addition of MTT to each well. Finally, the plates were incubated for $3 \mathrm{~h}$ and DMSO was added to each well. Absorbance was measured at $550 \mathrm{~nm}$ using BIORAD, PR 4100 multiplate reader. The optical density was directly related to the number of viable cells. The cytotoxicity was indicated by the decrease in the optical density as compared to control. Extract concentration which causes 50\% inhibition in comparison to control (cell growth $=100 \%$ ) was determined as $\mathrm{IC}_{50}$.

\subsection{Antimicrobial Assays}

2.5.1. Test Microorganisms. The ethanol extract was further tested against three standard Gram-positive bacterial strains including Staphylococcus aureus (ATCC 254996), Enterococcus faecalis (ATCC 254602), and Streptococcus pneumonia (ATCC 254657), four standard Gram-negative bacterial strains, Escherichia coli (ATCC 254607), Proteus mirabilis (ATCC 257440), Pseudomonas aeruginosa (ATCC 254992), and Klebsiella pneumoniae (ATCC 254656), one standard fungal strain, Candida albicans (ATCC 254625), and two clinical strains Streptococcus mutans and Lactobacillus spp. The tested organisms were procured from the Department of Microbiology, King Fahad Hospital, Jazan, Saudi Arabia.
2.5.2. Preparation of the Test Organisms. A loopful of isolated bacterial colonies were inoculated into $4 \mathrm{~mL}$ peptone water and incubated at $37^{\circ} \mathrm{C}$ for $4 \mathrm{~h}$. The turbidity of actively growing bacterial suspension was adjusted to match the turbidity standard of $0.5 \mathrm{McFarland}$ units [19]. The fungal cultures were maintained on Sabouraud dextrose agar, incubated at $25^{\circ} \mathrm{C}$ for 4 days. The fungal growth was harvested and washed off with $100 \mathrm{~mL}$ sterile normal saline, and the suspension was stored in the refrigerator at $4^{\circ} \mathrm{C}$ until used.

\subsubsection{In Vitro Antimicrobial Activity Testing of Extracts.} To test the antibacterial efficacy of the extract, a measured quantity $(1 \mathrm{~mL})$ of the standardized stock suspension of bacteria having $10^{5}-10^{6} \mathrm{CFU}$ per milliliter was mixed with $100 \mathrm{~mL}$ of Mueller-Hinton agar medium maintained at $45^{\circ} \mathrm{C}$. Aliquots $(20 \mathrm{~mL})$ of the resulting inoculated Mueller-Hinton agar medium were divided into previously sterilized plates. The agar medium was allowed to set at room temperature and 4 cups of $10 \mathrm{~mm}$ diameter were made in each of these plates using a sterilized cork borer (No. 4). Agar discs were removed and the hole was filled with different concentrations $(100 \mu \mathrm{g} / \mathrm{mL}$ and $500 \mu \mathrm{g} / \mathrm{mL})$ of ethanol extract and left undisturbed at room temperature to diffuse for $2 \mathrm{~h}$. The resulting plates were allowed to incubate at $37^{\circ} \mathrm{C}$ overnight. The plates were then observed for any inhibition in the bacterial growth and the diameter of zone of inhibition was measured. The method used for antibacterial study was also adopted for testing the extract for antifungal activity. The only difference in the method is that instead of Mueller-Hinton agar medium, another medium (Sabouraud dextrose agar medium) was used and the inoculated medium was maintained at $25^{\circ} \mathrm{C}[20]$.

2.5.4. Determination of MIC. Determination of MIC for the ethanol extract was accomplished against Streptococcus mutans. Tested bacterial cultures $(100 \mu \mathrm{L}$ of bacterial culture containing $10^{5} \mathrm{CFU} / \mathrm{mL}$ ) were inoculated into tubes containing different concentrations $(3.12,6.25,12.5$, and $25 \mathrm{mg} / \mathrm{mL}$ ) of ethanol extract and incubated at $37^{\circ} \mathrm{C}$ for $24 \mathrm{~h}$. The values were determined by detecting the inhibition of visible growth in the culture tubes. Minimum Bacterial Concentration (MBC) was assayed by subculturing the broth onto freshly prepared solid media and further incubated at $37^{\circ} \mathrm{C}$ for $24 \mathrm{~h}$ [21].

\section{Results and Discussion}

The total ion chromatogram of ethanol extract of the $S$. persica fruits is shown in Figure 1, which represents retention times of all the components detected in the extract. The chemical composition and documented biological activities of various components of ethanol extract of the fruits of $S$. persica are tabulated in Table 1. The ethanol extract consisted mainly of six esters (20.71\%), seven alkanes (15.47\%), tetracosamethyl-cyclododecasiloxane (9.91\%), eicosamethyl-cyclodecasiloxane (7.27), and 1-monolinoleoylglycerol (5.17). The predominant constituents were acetyl dasycarpidan-1-methanol (10.47\%), tetracosamethyl- 
TABLe 1: GC-MS analysis of the ethanol extract of $S$. persica fruits.

\begin{tabular}{|c|c|c|c|c|c|c|}
\hline S. no. & $\begin{array}{l}\text { Retention } \\
\text { time }\end{array}$ & Chemical constituents & $\begin{array}{c}\% \\
\text { area }\end{array}$ & $\begin{array}{l}\text { Molecular } \\
\text { formula }\end{array}$ & MW & Reported activity* \\
\hline 1 & 8.40 & $\begin{array}{l}\text { 3,3-Diisopropoxy-1,1,1,5,5,5- } \\
\text { hexamethyltrisiloxane }\end{array}$ & 0.82 & $\mathrm{C}_{12} \mathrm{H}_{32} \mathrm{O}_{4} \mathrm{Si}_{3}$ & 324 & - \\
\hline 2 & 10.87 & Benzoic acid, methyl ester & 0.84 & $\mathrm{C}_{8} \mathrm{H}_{8} \mathrm{O}_{2}$ & 136 & Antibacterial \\
\hline 3 & 18.22 & 2,2,4-Trimethyl-1,3-pentanediol & 1.1 & $\mathrm{C}_{16} \mathrm{H}_{30} \mathrm{O}_{4}$ & 286 & Antimicrobial \\
\hline 4 & 18.90 & $\begin{array}{c}\text { Propanoic acid, 2-methyl-, 3-hydroxy-2,4,4- } \\
\text { trimethylpentyl ester }\end{array}$ & 1.42 & $\mathrm{C}_{12} \mathrm{H}_{24} \mathrm{O}_{3}$ & 216 & \\
\hline 5 & 24.36 & Cyclooctasiloxane, hexadecamethyl- & 0.76 & $\mathrm{C}_{16} \mathrm{H}_{48} \mathrm{O}_{8} \mathrm{Si}_{8}$ & 592 & Antimicrobial \\
\hline 6 & 20.51 & Cycloheptasiloxane, tetradecamethyl- & 1.09 & $\mathrm{C}_{14} \mathrm{H}_{42} \mathrm{O}_{7} \mathrm{Si}_{7}$ & 518 & Preservative \\
\hline 7 & 27.66 & Cyclononasiloxane, octadecamethyl- & 1.09 & $\mathrm{C}_{18} \mathrm{H}_{54} \mathrm{O}_{9} \mathrm{Si}_{9}$ & 666 & Antifungal \\
\hline 8 & 28.24 & 3,5-Di-tert-butyl-4-hydroxybenzaldehyde & 1.00 & $\mathrm{C}_{15} \mathrm{H}_{22} \mathrm{O}_{2}$ & 234 & Antioxidant \\
\hline 9 & 31.27 & $\begin{array}{l}\text { 7,9-Di-tert-butyl-1-oxaspiro(4,5)deca-6,9-diene- } \\
\text { 2,8-dione }\end{array}$ & 3.76 & $\mathrm{C}_{17} \mathrm{H}_{24} \mathrm{O}_{3}$ & 276 & Antioxidant \\
\hline 10 & 31.72 & Nonadecane, 2-methyl- & 4.76 & $\mathrm{C}_{20} \mathrm{H}_{42}$ & 282 & Antioxidant \\
\hline 11 & 32.08 & Heptacosane & 3.33 & $\mathrm{C}_{27} \mathrm{H}_{56}$ & 380 & Antibacterial \\
\hline 12 & 32.26 & Eicosane, 7-hexyl- & 1.30 & $\mathrm{C}_{26} \mathrm{H}_{54}$ & 366 & $\begin{array}{l}\text { Antiandrogenic, aldose } \\
\text { reductase inhibitor }\end{array}$ \\
\hline 13 & 37.05 & Eicosane, 2-methyl- & 1.26 & $\mathrm{C}_{21} \mathrm{H}_{44}$ & 296 & $\begin{array}{l}\text { Antitumor, hemolytic activity, } \\
\text { cytotoxic, antioxidant }\end{array}$ \\
\hline 14 & 43.13 & Octadecane, 3-ethyl-5-(2-ethylbutyl)- & 2.33 & $\mathrm{C}_{26} \mathrm{H}$ & 366 & Antimicrobial, antifungal \\
\hline 15 & 43.37 & Tetratetracontane & 2.51 & $\mathrm{C}_{44} \mathrm{H}_{90}$ & 618 & Antioxidant, hypoglycemic \\
\hline 16 & 48.68 & 1-Monolinoleoylglycerol trimethylsilyl ether & 5.17 & $\mathrm{C}_{27} \mathrm{H}_{54} \mathrm{O}_{4} \mathrm{Si}_{2}$ & 498 & Antimicrobial \\
\hline 17 & 50.50 & $\begin{array}{c}\text { psi,psi-Carotene, } 7,7^{\prime}, 8,8^{\prime}, 11,11^{\prime}, 12,12^{\prime}, 15,15^{\prime}- \\
\text { decahydro- }\end{array}$ & 0.78 & $\mathrm{C}_{40} \mathrm{H}_{66}$ & 546 & Antioxidant \\
\hline 18 & 52.05 & Cyclodecasiloxane, eicosamethyl- & 7.27 & $\mathrm{C}_{20} \mathrm{H}_{60} \mathrm{O}_{10} \mathrm{Si}_{10}$ & 742 & Antimicrobial \\
\hline 19 & 52.37 & Dasycarpidan-1-methanol, acetate (ester) & 10.49 & $\mathrm{C}_{20} \mathrm{H}_{26} \mathrm{~N}_{2} \mathrm{O}_{2}$ & 326 & Anti-inflammatory \\
\hline 20 & 55.93 & Heptasiloxane, hexadecamethyl- & 0.72 & $\mathrm{C}_{16} \mathrm{H}_{48} \mathrm{O}_{6} \mathrm{Si}_{7}$ & 532 & Antimicrobial \\
\hline 21 & 56.57 & $\begin{array}{c}\text { á,psi-Carotene, } 3^{\prime}, 4^{\prime} \text {-didehydro- } 1^{\prime}, 2^{\prime} \text {-dihydro- } \\
1^{\prime}, 2^{\prime} \text {-dihydroxy-, }\left(2^{\prime} \mathrm{R}\right) \text { - }\end{array}$ & 1.24 & $\mathrm{C}_{40} \mathrm{H}_{56} \mathrm{O}_{2}$ & 568 & Anticancer, antioxidant \\
\hline 22 & 60.44 & $\begin{array}{l}\text { Milbemycin B, 5-demethoxy-5-one-6,28-anhydro- } \\
\text { 25-ethyl-4-methyl-13-chloro-oxime }\end{array}$ & 1.21 & $\mathrm{C}_{32} \mathrm{H}_{44} \mathrm{ClNO}_{7}$ & 589 & Antibacterial, antifungal \\
\hline 23 & 66.02 & $\begin{array}{c}\text { 9-Octadecenoic acid (Z)-, 3-[(1-oxohexadecyl)oxy]- } \\
\text { 2-[(1-oxooctadecyl)oxy]propyl ester }\end{array}$ & 1.61 & $\mathrm{C}_{55} \mathrm{H}_{10} 4 \mathrm{O}_{6}$ & 860 & Emulsifying agent \\
\hline 24 & 66.45 & $\begin{array}{l}\text { 9,12,15-Octadecatrienoic acid, 2,3-bis } \\
\text { [(trimethylsilyl)oxy]propyl ester, }(\mathrm{Z}, \mathrm{Z}, \mathrm{Z}) \text { - }\end{array}$ & 3.49 & $\mathrm{C}_{27} \mathrm{H}_{52} \mathrm{O}_{4} \mathrm{Si}_{2}$ & 496 & Anticancer, hepatoprotective \\
\hline 25 & 66.63 & $\begin{array}{l}\text { 9-Octadecenoic acid, 1,2,3-propanetriyl ester, } \\
\text { (E,E,E)- }\end{array}$ & 2.86 & $\mathrm{C}_{57} \mathrm{H}_{10} 4 \mathrm{O}_{6}$ & 884 & Antibacterial, anticancer \\
\hline 26 & 67.74 & Formyl colchicine & 2.22 & $\mathrm{C}_{23} \mathrm{H}_{25} \mathrm{NO}_{7}$ & 427 & $\begin{array}{l}\text { Anti-inflammatory, } \\
\text { antioxidant, cytotoxic activity }\end{array}$ \\
\hline 27 & 69.86 & $\begin{array}{c}\text { psi,psi-Carotene, } 1,1^{\prime}, 2,2^{\prime} \text {-tetrahydro- } 1,1^{\prime} \text { - } \\
\text { dimethoxy- }\end{array}$ & 3.33 & $\mathrm{C}_{42} \mathrm{H}_{64} \mathrm{O}_{2}$ & 600 & Antioxidant \\
\hline
\end{tabular}

*Activity reported from Dr. Duke's Phytochemical and Ethnobotanical Databases [42].

TABle 2: GC-MS analysis of petroleum ether extract of $S$. persica fruits.

\begin{tabular}{|c|c|c|c|c|c|c|}
\hline S. no. & $\begin{array}{l}\text { Retention } \\
\text { time }\end{array}$ & Chemical constituents & $\begin{array}{c}\% \\
\text { area }\end{array}$ & $\begin{array}{l}\text { Molecular } \\
\text { formula }\end{array}$ & MW & Reported activity* \\
\hline 1 & 8.42 & Cyclotrisiloxane, hexamethyl- & 0.74 & $\mathrm{C}_{6} \mathrm{H}_{18} \mathrm{O}_{3} \mathrm{Si}_{3}$ & 222 & Anticancer \\
\hline 2 & 10.90 & Benzoic acid, methyl ester & 0.66 & $\mathrm{C}_{8} \mathrm{H}_{8} \mathrm{O}_{2}$ & 136 & Antibacterial \\
\hline 3 & 18.95 & $\begin{array}{l}\text { Propanoic acid, 2-methyl-, 2,2-dimethyl-1-(2- } \\
\text { hydroxy-1-methylethyl)propyl ester }\end{array}$ & 1.51 & $\mathrm{C}_{12} \mathrm{H}_{24} \mathrm{O}_{3}$ & 216 & \\
\hline 4 & 27.49 & Heptadecane, 2,6,10,15-tetramethyl- & 1.12 & $\mathrm{C}_{21} \mathrm{H}_{44}$ & 296 & \\
\hline 5 & 31.32 & $\begin{array}{l}\text { 7,9-Di-tert-butyl-1-oxaspiro(4,5)deca-6,9-diene- } \\
\text { 2,8-dione }\end{array}$ & 2.52 & $\mathrm{C}_{17} \mathrm{H}_{24} \mathrm{O}_{3}$ & 276 & Antioxidant \\
\hline 6 & 31.77 & Eicosane, 2-methyl- & 1.7 & $\mathrm{C}_{21} \mathrm{H}_{44}$ & 296 & $\begin{array}{l}\text { Antitumor, hemolytic activity, } \\
\text { cytotoxic, antioxidant }\end{array}$ \\
\hline 7 & 32.13 & Nonadecane, 2-methyl- & 1.61 & $\mathrm{C}_{20} \mathrm{H}_{42}$ & 282 & Antioxidant \\
\hline 8 & 32.31 & 1-Iodo-2-methylundecane & 0.76 & $\mathrm{C}_{12} \mathrm{H}_{25} \mathrm{I}$ & 296 & \\
\hline 9 & 37.23 & Cyclononasiloxane, octadecamethyl- & 2.33 & $\mathrm{C}_{18} \mathrm{H}_{54} \mathrm{O}_{9} \mathrm{Si}_{9}$ & 666 & Antifungal \\
\hline
\end{tabular}


TABLE 2: Continued.

\begin{tabular}{|c|c|c|c|c|c|c|}
\hline S. no. & $\begin{array}{l}\text { Retention } \\
\text { time }\end{array}$ & Chemical constituents & $\begin{array}{c}\% \\
\text { area }\end{array}$ & $\begin{array}{l}\text { Molecular } \\
\text { formula }\end{array}$ & MW & Reported activity* \\
\hline 10 & 42.64 & Octadecane, 3-ethyl-5-(2-ethylbutyl)- & 2.53 & $\mathrm{C}_{26} \mathrm{H}_{54}$ & 366 & \\
\hline 11 & 52.08 & Cyclodecasiloxane, eicosamethyl- & 23.81 & $\mathrm{C}_{20} \mathrm{H}_{60} \mathrm{O}_{10} \mathrm{Si}_{10}$ & 742 & $\begin{array}{l}\text { Antimicrobial, antihelmintic, } \\
\text { antioxidant }\end{array}$ \\
\hline 12 & 56.22 & Tetracosamethyl-cyclododecasiloxane & 9.91 & $\mathrm{C}_{24} \mathrm{H}_{72} \mathrm{O}_{12} \mathrm{Si}_{12}$ & 890 & $\begin{array}{c}\text { Hepatoprotective, } \\
\text { antispasmodic, antirheumatic }\end{array}$ \\
\hline 13 & 48.68 & $\begin{array}{l}\text { 1-Monolinoleoylglycerol trimethylsilyl ether } \\
\text { 9,12,15-Octadecatrienoic acid, 2-[(trimethylsilyl) }\end{array}$ & 11.78 & $\mathrm{C}_{27} \mathrm{H}_{54} \mathrm{O}_{4} \mathrm{Si}_{2}$ & 498 & Antimicrobial \\
\hline 14 & 65.99 & $\begin{array}{c}\text { oxy }]-1-[[(\text { trimethylsilyl)oxy]methyl }] \text { ethyl ester, } \\
(\mathrm{Z}, \mathrm{Z}, \mathrm{Z})-\end{array}$ & 10.56 & $\mathrm{C}_{27} \mathrm{H}_{52} \mathrm{O}_{4} \mathrm{Si}_{2}$ & 496 & Anticancer, anti-inflammatory \\
\hline
\end{tabular}

*Activity reported from Dr. Duke's Phytochemical and Ethnobotanical Databases.

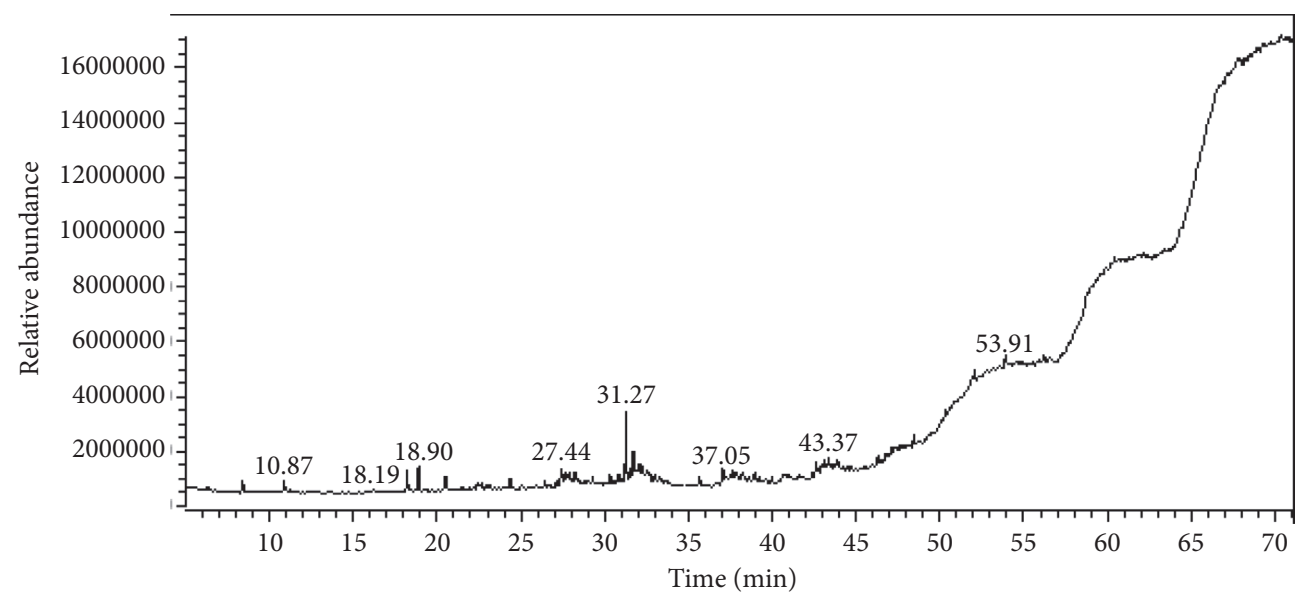

Figure 1: Total ion GC-MS chromatogram of the ethanol extract of $S$. persica fruits.

cyclododecasiloxane (9.91\%), eicosamethyl-cyclodecasiloxane (7.27\%), and 1-monolinoleoylglycerol (5.17). The major alkanes detected were 2-methyl nonadecane $(4.76 \%)$ and heptacosane $(3.31 \%)$. Five compounds were detected in trace amounts. Two carotene derivatives, $\left(2^{\prime} R\right)$ $3^{\prime}, 4^{\prime}$-didehydro- $1^{\prime}, 2^{\prime}$-dihydro- $1^{\prime}, 2^{\prime}$-dihydroxy- $\alpha$ - $p s i$-carotene $(1.24 \%)$ and $1,1^{\prime}, 2,2^{\prime}$-tetrahydro-1,1'-dimethoxypsi,psi-carotene $(3.33 \%)$, were also detected for the first time in the S. persica fruits. Formyl colchicine $(2.22 \%)$ was an alkaloidal constituent present in the fruits. The fruits were found to be devoid of phytosterol, fatty acids, saponins, and mono-, di-, and triterpenoids. The chemical components methyl benzoate $(0.66 \%)$, 2-methyl nonadecane, 2-methyl eicosane, 3-ethyl-5-(2-ethylbutyl)-octadecane, 7,9-di-tertbutyl-1-oxaspiro $(4,5)$ deca-6,9-diene-2,8-dione $(2.52 \%)$, and 1 -monolinoleoylglycerol $(11.78 \%)$ were also detected in the ethanol extract of the fruits.

Similarly, the total ion chromatogram of petroleum ether extract was obtained using GC-MS and is shown as Figure 2, whereas the chemical constituents and major biological activities of the petroleum ether extract of the $S$. persica fruits are summarized in Table 2. The prominent constituents characterized in the petroleum ether were eicosamethylcyclodecasiloxane (23.81\%), 1-monolinoleoylglycerol (11.78\%), (Z,Z,Z)-9,12,15-octadecatrienoic acid ethyl ester derivative (10.56\%), and tetracosamethyl-cyclododecasiloxane (9.91\%). Four alkanes identified in the extract included 2,6,10,15-tetramethyl heptadecane (1.12\%), 2methyl eicosane (1.7\%), 2-methyl nonadecane $(1.61 \%)$, and 3-ethyl-5-(2-ethylbutyl)-octadecane (2.53\%). Figure 3 represents various important chemical constituents detected in ethanol and petroleum ether extracts of fruits of S. persica along with their structure.

The previous phytochemical screening studies showed that the stem of $S$. persica yielded octacosanol, 1-triacantanol, $\beta$-sitosterol, 3-O- $\beta$-D-glucopyranoside salvadourea, $m$-anisic acid $[22,23]$, pyrrolidine, pyrrole, and piperidine derivatives [24], salvadoside and salvadoraside glycosides [25], and flavonoids, which included quercetin, rutin, kaempferol, and quercetin glucoside [26], while the roots of $S$. persica yielded $\beta$-sitosteryl fatty esters and $\beta$-sitosteryl-3-vanilloyl-4'-fatty esters [27]. The roots, leaves, and stem contained ascorbic acid, butanediamide, salvadorine, salvadourea, lignans, fatty acids, trimethyl amine, cyanogenic glycosides, steroidal esters, tannins, aniline derivative, spiculesporic acid, methyl hexadecanoate, and homo- $\gamma$-linolenic acid [28]. Additionally, the stem essential oil is reported to consist mainly of 1,8-cineole (eucalyptol) (46\%), $\beta$-pinene (6.3\%), and 9-epi-(E)-caryophyllene (13.4\%) [29]. The roots and stems also possessed oleic, 


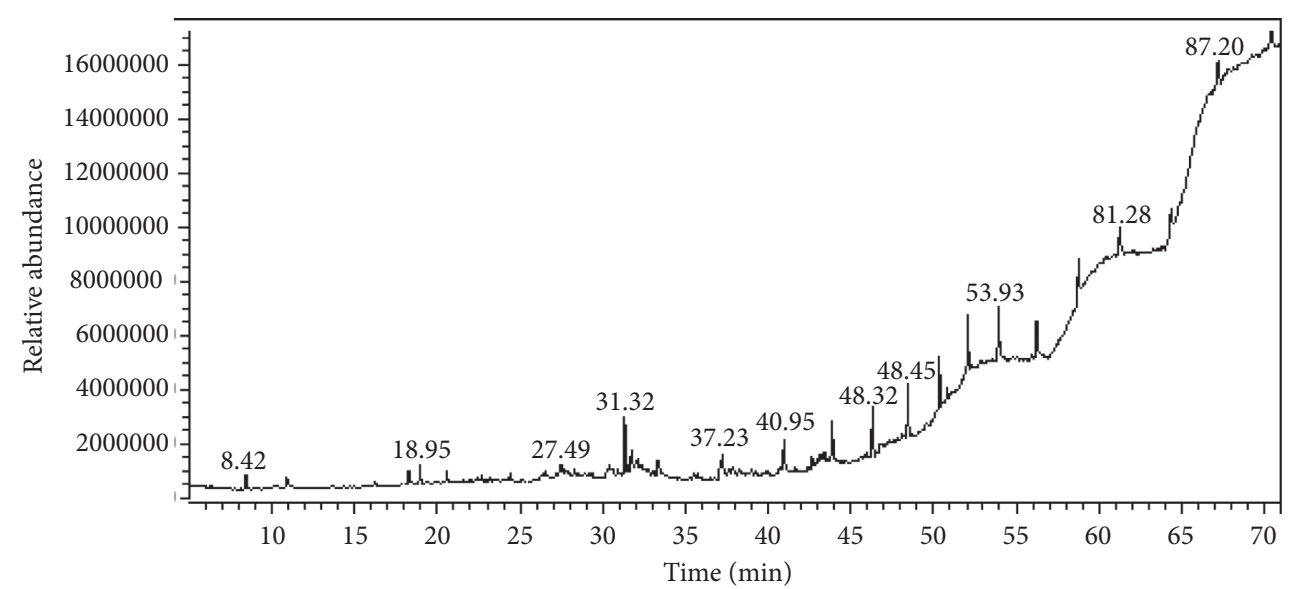

Figure 2: Total ion GC-MS chromatogram of the petroleum ether extract of $S$. persica fruits.

linoleic, and stearic acids as well as methyl and ethyl esters of fatty and other organic acids [30].

The ethanol fruit extract of $S$. persica was tested for cytotoxic effects using MTT assay (72 h), which showed activity against the breast, ovary, and colon cancer cells (IC50: $5.12-17.50 \mu \mathrm{g} / \mathrm{mL})$. However, it was observed to be more selective against the ovarian and the colon cancer cell lines compared to the normal cells MRC5 (Table 3, Figure 4). This result was in agreement with the previous reports showing the antitumor activity of $S$. persica root, sticks, and bark extracts against oral carcinoma, HepG2, MCF7, A549, and HCT116 cancer cells [31-36]. Both S. persica fruit extract used in this study and $S$. persica root extract previously tested have exhibited protection to the normal lung and oral cells, thus indicating the safety profile of this commonly used plant. Eicosane, psi-carotene, $3^{\prime}, 4^{\prime}$-didehydro- $1^{\prime}, 2^{\prime}$-dihydro- $1^{\prime}, 2^{\prime}$ dihydroxy-(2'R)-9,12,15-octadecatrienoic acid, 2,3-bis[(trimethylsilyl)oxy]propyl ester, $(Z, Z, Z)$-, and formyl colchicine were all identified in the GC-MS analysis of the ethanol extract of $S$. persica fruits in this study. These constituents were previously reported to exert anticancer activities according to Dr. Duke's Phytochemical and Ethnobotanical Databases (Table 1) [16].

The antibacterial activity of the ethanol extract was determined using the disc diffusion method. The plant extract was found to possess selective antimicrobial activity, as it was ineffective at both the tested concentrations $(100 \mu \mathrm{g} / \mathrm{mL}$ and $500 \mu \mathrm{g} / \mathrm{mL})$ against the isolates of Staphylococcus aureus and Enterococcus faecalis as well as against the Gram-negative microorganisms, Escherichia coli, Proteus mirabilis, Pseudomonas aeruginosa, and Klebsiella pneumonia. Interestingly, it was found to be selectively effective against the isolates of Streptococcus mutans, which was resistant to the standard drug Ampicillin. The zone of inhibition at the higher concentration $500 \mu \mathrm{g} / \mathrm{mL}$ was found to be $25 \pm 2.1 \mathrm{~mm}$ which was comparable to the zone of inhibition shown by ampicillin for other bacterial strains at the same concentration (Table 4). The MIC and MBC values of the extract were 3.12 and $6.25 \mathrm{mg} / \mathrm{mL}$, respectively, whereas the standard drug ampicillin was found to have nonsignificant activity against the tested strain. This could mainly be due to the phytochemical differences between the constituents in the fruits of S. persica collected from this region or to the characteristic differences between S. mutans and other bacterial strains used in this study. This could also be attributed to any potential to new characters that could have been gained by the clinical strains that showed resistance against $S$. persica extracts. On the other hand, the sensitivity of $S$. mutans to the extract of $S$. persica supports the traditional use of this plant in oral health as it is considered one of the most common oral microbes that cause caries.

Interestingly, previous reports of in vitro antibacterial and antifungal studies on roots and stem extracts of $S$. persica on cariogenic bacteria and periodontal pathogens showed that the plant was effective against $S$. faecalis, $S$. aureus, S. pyogenes, S. mutans, $P$. aeruginosa, L. acidophilus, $P$. gingivalis, $H$. influenzae, $A$. actinomycetemcomitans, and C. albicans [37-39]. However, this study utilized the fruits of $S$. persica and included additional bacterial strains such as $E$. faecalis, E. coli, P. mirabilis, and K. pneumonia for antibacterial activity, but the fruits extract of the collected plant was ineffective against all these strains.

Previously, the roots and stem of $S$. persica used as toothbrushes showed antimicrobial, antiplaque, aphrodisiac, analgesic, alexiteric, antipyretic, anti-inflammatory, and astringent effects, which help in cleaning the teeth and decreasing tooth decay $[40,41]$. In another study, the bioactive compounds extracted from $S$. persica roots and stems showed wide scope of pharmacological activities including antimicrobial, antioxidant, antiulcer, anticonvulsant, sedative, antiplasmodia, antimalarial, analgesic, antitumor, scurvy, gonorrhea, boils, antiosteoporosis, enzyme inhibitory activity, anti-inflammatory, hypoglycemic, 
TABLE 3: Cytotoxic activity of the ethanol extract of the $S$. persica fruits against three cancer cell lines and one normal fibroblast (MTT $72 \mathrm{~h}$ $\left.\mathrm{IC}_{50} \pm \mathrm{SD} \mu \mathrm{g} / \mathrm{mL}\right)$.

\begin{tabular}{|c|c|c|c|c|}
\hline \multirow{2}{*}{ Extract } & \multicolumn{4}{|c|}{$\mathrm{IC}_{50}(\mu \mathrm{g} / \mathrm{mL})$} \\
\hline & MCF7 & A2780 & HT29 & MRC5 \\
\hline Fruits of $S$. persica L. & $17.50 \pm 0.46$ & $8.35 \pm 0.77$ & $5.12 \pm 1.37$ & $13.74 \pm 2.27$ \\
\hline
\end{tabular}
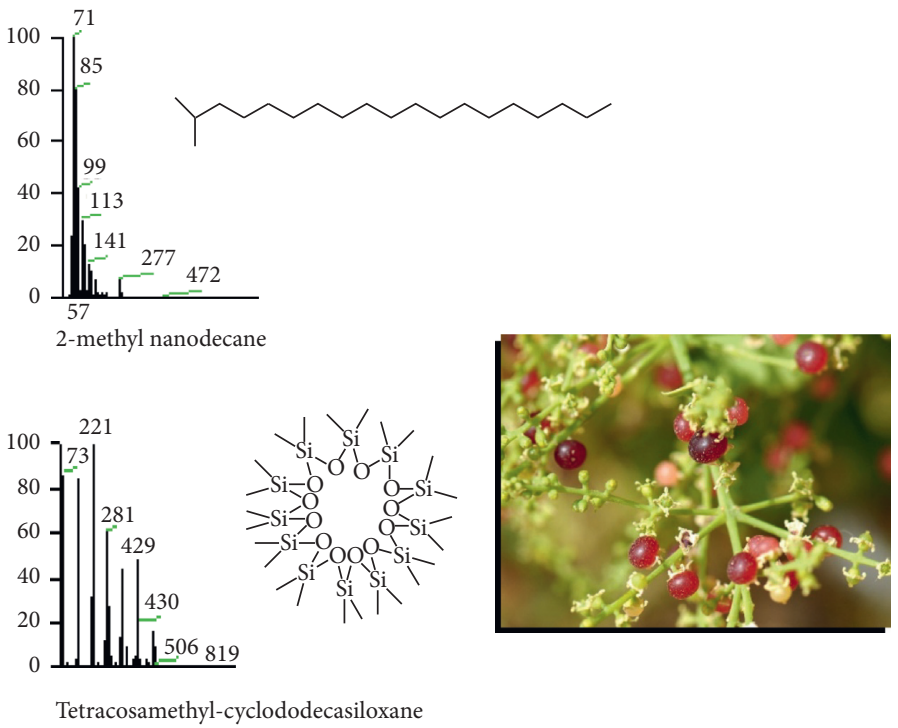

Tetracosamethyl-cyclododecasiloxane


Dasycarpidan-1-methnol,acetate (ester)
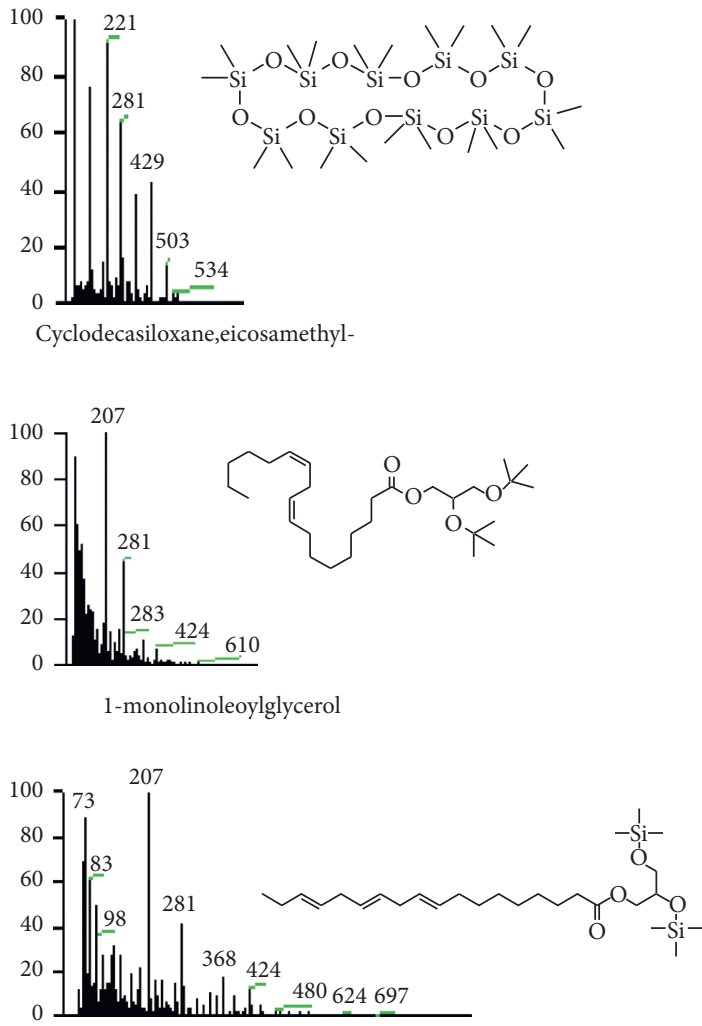

9,12,15-octadecatrienoic acid 2,3-bis[(trimethylsilyl)oxy]propyl ester,(ZZZ)-

FIgURE 3: Major bioactive components detected in S. persica fruits using GC-MS.

hypolipidemic, anticonvulsion, diuretic, and bitter stomachic activities, in addition to antiurolithiatic properties [31-36, 42, 43]. Benzyl isothiocyanate and benzyl nitrile were major active compounds purified from $S$. persica with powerful antibacterial and antifungal activity [27, 44, 45]. Benzyl isothiocyanate is extracted from the mouth when chewing sticks were used more than once for 10 minutes. The essential oils present in the sticks showed positive effect on gingival fibroblasts and resistance towards oral keratinocytes [46]. $N$-Benzylbenzamide isolated from the roots of $S$. persica exhibited a considerable inhibitory activity against the collagen-induced platelet aggregation in human and a considerable antiseptic against E. coli [47]. S. persica stem was also reported to act as a protectant against the pentylenetetrazol-induced convulsions in humans by extending the sleeping period and decreasing the induction time induced by sodium pentobarbital [36]. Moreover, Persicaline, a sulphur-containing imidazoline alkaloid, and three furan derivatives with hydroxyl groups were identified from the root of S. persica, which showed promising antioxidant activity as compared to ascorbic acid $[48,49]$.

The prevalence of dental caries was reported to be remarkably low in the users of S. persica stem due to the presence of strong antimicrobial thiocyanate component along with other substances such as potassium chloride, sodium chloride, tannins, and saponins [50]. The ethanol extract of $S$. persica stem exhibited substantial decrease in the cariogenic bacterial growth and dental decay [50]. Additionally, data obtained from controlled clinical trials 







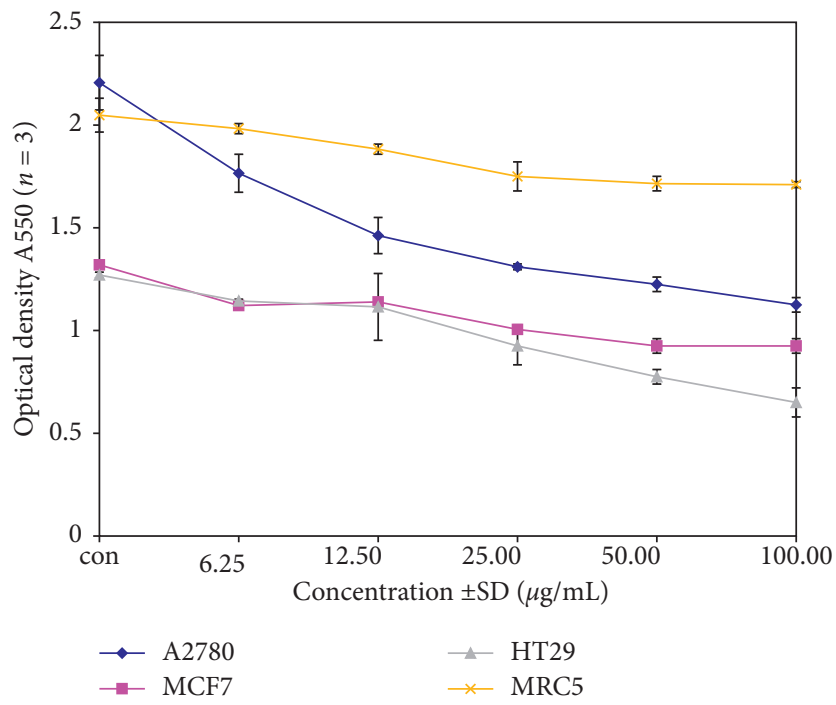

FIGURE 4: Cytotoxic effects of ethanol extract of S. persica fruits on A2780, MCF7, HT29, and MRC5 cells. Experiments were repeated three times.

revealed that the extract of $S$. persica roots and stem is also effective antimicrobial if used as an irritant for treating necrotic pulp teeth [51-53].

\section{Conclusion}

Forty-one phytochemicals were identified from the ethanol and petroleum ether extracts of the fruits of S. persica grown in the southern region of Saudi Arabia using GC-MS. The ethanol extract showed good cytotoxic properties against ovary and colon cancer cells and lesser cytotoxicity against the MRC5 normal cells. Further studies are required to establish the cytotoxic effects of the extract and identification of components acting as cytotoxic. The fruit extract of $S$. persica has also demonstrated potential antimicrobial activity against $S$. mutans which was resistant to the standard drug ampicillin. This study suggested a new potential ethnopharmacological use of S. persica fruits along with the roots and stem of the plant in dental care and for other related ailments.

\section{Data Availability}

All the data related to the study are available through the corresponding author and can be provided upon request.

\section{Conflicts of Interest}

The authors declare no conflicts of interest regarding the publication of this paper.

\section{Acknowledgments}

The authors are thankful to the Deanship of Scientific Research, Jazan University, for providing financial assistance (Research Group no. RG-3-9) to carry out this research work.

\section{References}

[1] Anonymous, The Wealth of India- Raw Materials, vol. 9, pp. 193-195, CSIR, New Delhi, India, 1972.

[2] H. S. Halawany, "A review on miswak (Salvadora persica) and its effect on various aspects of oral health," The Saudi Dental Journal, vol. 24, no. 2, pp. 63-69, 2012.

[3] S. Ali, E. Nasir, and S. Qureshi, Flora of West Pakistan. No. 29, Salvadoraceae, University of Karachi, Karachi, Pakistan, 1972.

[4] U. Quattrocchi, CRC World Dictionary of Medicinal and Poisonous Plants: Common Names, Scientific Names, Eponyms, Synonyms, and Etymology (5 Volume Set), CRC Press, Boca Raton, FL, USA, 2016.

[5] M. I. Gazi, T. J. Davies, N. AI-Bagieh, and S. W. Cox, "The immediate- and medium-term effects of Meswak on the composition of mixed saliva," Journal of Clinical Periodontology, vol. 19, no. 2, pp. 113-117, 1992.

[6] T. Al lafi and H. Ababneh, "The effect of the extract of the miswak (chewing sticks) used in Jordan and the Middle East on oral bacteria," International Dental Journal, vol. 45, no. 3 , pp. 218-222, 1995.

[7] K. Almas, "Miswak (chewing stick) and its role in oral health," Postgraduate Dentist, vol. 3, no. 4, pp. 214-218, 1993.

[8] S. A. Mohamed, Y. Q. Almulaiky, Y. M. Ahmed, O. A. M. AlBar, and I. H. Ibrahim, "Purification and characterization of $\alpha$-amylase from miswak Salvadora persica," BMC Complementary and Alternative Medicine, vol. 14, Article ID 119, 2014.

[9] M. S. Akhtar and M. Ajmal, "Significance of chewing-sticks (miswaks) in oral hygiene from a pharmacological viewpoint," Journal of Pakistan Medical Association, vol. 31, no. 4, pp. 89-95, 1981.

[10] H. Hammad, M. Khaled, K. Al-Qaoud, and M. M. Hammad, "Effect of Salvadora persica Linn root aqueous extract on oral epithelial dysplasia and oral cancer cell lines," Tropical Journal of Pharmaceutical Research, vol. 18, no. 12, pp. 2591-2596, 2019.

[11] A. Y. Ibrahim, S. E. El-Gengaihi, and H. M. Motawe, "Phytochemical and cytotoxicity investigations of Salvadora 
persica bark extracts," Journal of The Arab Society for Medical Research, vol. 6, no. 2, pp. 127-133, 2011.

[12] A. Kumari, A. K. Parida, J. Rangani, and A. Panda, "Antioxidant activities, metabolic profiling, proximate analysis, mineral nutrient composition of Salvadora persica fruit unravel a potential functional food and a natural source of pharmaceuticals," Frontiers in Pharmacology, vol. 8, p. 61, 2017.

[13] H. Ahmad and K. Rajagopal, "Biological activities of Salvadora persica L. Meswak," Medicinal and Aromatic Plants, vol. 2, no. 4, pp. 1-5, 2013.

[14] E. Noumi, M. Snoussi, A. Merghni et al., "Phytochemical composition, anti-biofilm and anti-quorum sensing potential of fruit, stem and leaves of Salvadora persica L. methanolic extracts," Microbial Pathogenesis, vol. 109, pp. 169-176, 2017.

[15] J. Harborne, "Methods of plant analysis," in Phytochemical Methods, pp. 1-36, Springer, Berlin, Germany, 1984.

[16] US Department of Agriculture, Agricultural Research Service, Dr. Duke's Phytochemical and Ethnobotanical Databases, Agricultural Research Service, Washington, DC, USA, 19922020, https://phytochem.nal.usda.gov/.

[17] A. N. Abdalla, U. Shaheen, Q. M. A. Abdallah et al., "Proapoptotic activity of Achillea membranacea essential oil and its major constituent 1,8-cineole against A2780 ovarian cancer cells," Molecules, vol. 25, no. 7, p. 1582, 2020.

[18] U. Shaheen, E. A. Ragab, A. N. Abdalla, and A. Bader, "Triterpenoidal saponins from the fruits of Gleditsia caspica with proapoptotic properties," Phytochemistry, vol. 145, pp. 168-178, 2018.

[19] M. Cheesbrough, District Laboratory Practice in Tropical Countries, Cambridge University Press, Cambridge, MA, USA, 2006.

[20] F. Kavanagh, "An approach to accurate diffusion assays," in Analytical Microbiology, F. Kavanagh, Ed., pp. 31-42, Academic Press, Cambridge, MA, USA, 1972.

[21] M. A. Wikler, "Methods for dilution antimicrobial susceptibility tests for bacteria that grow aerobically: approved standard," CLSI (NCCLS), vol. 26, pp. M7-A7, 2006.

[22] M. Jain and V. Saxena, "Chemical constituents of the Stem of Salvadora persica," Acta Ciencia Indica, vol. 10, p. 127, 1984.

[23] A. B. Ray, L. Chand, and S. C. Dutta, "Salvadourea: a new urea derivative from Salvadora persica-Linn," Chemistry and Industry, vol. 12, pp. 517-518, 1975.

[24] G. C. Galletti, G. Chiavari, and Y. D. Kahie, "Pyrolysis/gas chromatography/ion-trap mass spectrometry of the "tooth brush" tree (Salvadora persica L.)," Rapid Communications in Mass Spectrometry, vol. 7, no. 7, pp. 651-655, 1993.

[25] K. Ohtani, R. Kasai, K. Yamasaki et al., "Lignan glycosides from stems of Salvadora persica," Phytochemistry, vol. 31, no. 7, pp. 2469-2471, 1992.

[26] S. Abdel-Wahab, M. Selim, and N. El-Fiki, "Investigation of the flavonoid content of Salvadora persica L," vol. 28, pp. 67-70, Bulletin of Faculty of Pharmacy, Cairo University, Giza, Egypt, 1990.

[27] M. Khan, M. YusufAl Robaian, and M. Ali, "Isolation and characterization of four novel $\beta$-Sitosteryl esters from Salvadora persica Linn," Natural Product Research, vol. 32, no. 14, pp. 1639-1647, 2018.

[28] M. El-Hefny, H. M. Ali, N. A. Ashmawy, and M. Z. M. Salem, "Chemical composition and bioactivity of Salvadora persica extracts against some potato bacterial pathogens," BioResources, vol. 12, no. 1, pp. 1835-1849, 2017.

[29] F. Alali, M. Hudaib, T. Aburjai, K. Khairallah, and N. AlHadidi, "GC-MS analysis and antimicrobial activity of the essential oil from the stem of the Jordanian toothbrush TreeSalvadora persica," Pharmaceutical Biology, vol. 42, no. 8, pp. 577-580, 2005.

[30] H. F. AbdELRahman, N. Skaug, A. M. Whyatt, and G. W. Francis, "Volatile compounds in crude Salvadora persica extracts," Pharmaceutical Biology, vol. 41, no. 6, pp. 399-404, 2003.

[31] M. Ahmad, H. Imran, Z. Yaqeen, and Z. Rehman, "Pharmacological profile of Salvadora persica," Pakistan Journal of Pharmaceutical Sciences, vol. 24, no. 3, pp. 323-330, 2011.

[32] N. Alili, J. C. Türp, E. M. Kulik, and T. Waltimo, "Volatile compounds of Salvadora persica inhibit the growth of oral Candida species," Archives of Oral Biology, vol. 59, no. 5, pp. 441-447, 2014.

[33] M. Z. Aumeeruddy, G. Zengin, and M. F. Mahomoodally, “A review of the traditional and modern uses of Salvadora persica L. (Miswak): toothbrush tree of Prophet Muhammad," Journal of Ethnopharmacology, vol. 213, pp. 409-444, 2018.

[34] K. Geetha, R. Manavalan, and D. Venkappayya, "Control of urinary risk factors of stone formation by Salvadora persica in experimental hyperoxaluria," Methods and Findings in Experimental and Clinical Pharmacology, vol. 32, no. 9, pp. 623-629, 2010.

[35] M. Khan, M. Ali, A. Ali, and S. R. Mir, "Hypoglycemic and hypolipidemic activities of Arabic and Indian origin Salvadora persica root extract on diabetic rats with histopathology of their pancreas," International Journal of Health Sciences, vol. 8, no. 1, pp. 45-56, 2014.

[36] M. T. Monforte, A. Trovato, A. Rossitto et al., "Anticonvulsant and sedative effects of Salvadora persica L. stem extracts," Phytotherapy Research, vol. 16, no. 4, pp. 395-397, 2002.

[37] S. G. Mohammed, "Comparative study of in vitro antibacterial activity of miswak extracts and different toothpastes," American Journal of Agricultural and Biological Sciences, vol. 8, no. 1, pp. 82-88, 2013.

[38] M. Fallah, F. Fallah, M. Kamalinejad, M. A. Malekan, Z. Akhlaghi, and M. Esmaeili, "The antimicrobial effect of aquatic extract of Salvadora persica on Mycobacterium bovis in vitro," International Journal of Mycobacteriology, vol. 4, pp. 167-168, 2015.

[39] S. Naseem, K. Hashmi, F. Fasih, S. Sharafat, and R. Khanani, "In vitro evaluation of antimicrobial effect of miswak against common oral pathogens," Pakistan Journal of Medical Sciences, vol. 30, no. 2, pp. 398-403, 2014.

[40] F. H. Niazi, M. A. Kamran, M. Naseem, I. AlShahrani, T. R. Fraz, and M. Hosein, "Anti-plaque efficacy of herbal mouthwashes compared to synthetic mouthwashes in patients undergoing orthodontic treatment: a randomised controlled trial," Oral Health and Preventive Dentistry, vol. 16, no. 5, pp. 409-416, 2018.

[41] K. Rezaei, S. Rezaei, M. Mahboubi et al., "Comparison the efficacy of herbal mouthwash with chlorhexidine on gingival index of intubated patients in Intensive Care Unit," Journal of Indian Society of Periodontology, vol. 20, no. 4, p. 404, 2016.

[42] M. H. Saleh, "Properties of peroxidase from chewing stick miswak," African Journal of Pharmacy and Pharmacology, vol. 6, no. 9, pp. 660-670, 2012.

[43] S. A. Mohamed and J. A. Khan, "Antioxidant capacity of chewing stick miswak Salvadora persica," BMC Complementary and Alternative Medicine, vol. 13, no. 1, p. 40, 2013.

[44] N. Fatima, W. Iqbal, and S. S. Yaqeen, "Evaluation of wound healing effects between Salvadora persica ointment and Solcoseryl jelly in animal model," Pakistan Journal of Pharmaceutical Sciences, vol. 28, no. 5, pp. 1777-1780, 2015. 
[45] M. Z. M. Salem, S. I. Behiry, and A. Z. M. Salem, "Effectiveness of root-bark extract from Salvadora persica against the growth of certain molecularly identified pathogenic bacteria," Microbial Pathogenesis, vol. 117, pp. 320-326, 2018.

[46] R. Albabtain, M. Azeem, Z. Wondimu, T. Lindberg, A. K. Borg-Karlson, and A. Gustafsson, "Investigations of a possible chemical effect of Salvadora persica chewing sticks," Evidence-Based Complementary and Alternative Medicine, vol. 2017, Article ID 2576548, 10 pages, 2017.

[47] A. T. Khalil, "Benzylamides fromSalvadora persica," Archives of Pharmacal Research, vol. 29, no. 11, pp. 952-956, 2006.

[48] M. Farag, W. Abdel-Mageed, O. Basudan, and A. El-Gamal, "Persicaline, a new antioxidant sulphur-containing imidazoline alkaloid from Salvadora persica roots," Molecules, vol. 23, no. 2, p. 483, 2018.

[49] M. A. Lebda, A. H. El-Far, A. E. Noreldin, Y. H. A. Elewa, S. K. Al Jaouni, and S. A. Mousa, "Protective effects of miswak (Salvadora persica) against experimentally induced gastric ulcers in rats," Oxidative Medicine and Cellular Longevity, vol. 2018, Article ID 6703296, 14 pages, 2018.

[50] F. A. Al-Bayati and K. D. Sulaiman, "In vitro antimicrobial activity of Salvadora persica L. extracts against some isolated oral pathogens in Iraq," Turkish Journal of Biology, vol. 32, no. 1, pp. 57-62, 2008.

[51] P. K. Bhat, A. Kumar, and S. Sarkar, "Assessment of immediate antimicrobial effect of miswak extract and toothbrush oncariogenic bacteria-a clinical study," Journal of Advanced Oral Research, vol. 3, no. 1, pp. 25-29, 2012.

[52] N. Chelli-Chentouf, A. Tir Touil Meddah, C. Mullié, A. Aoues, and B. Meddah, "In vitro and in vivo antimicrobial activity of Algerian Hoggar Salvadora persica L. extracts against microbial strains from children's oral cavity," Journal of Ethnopharmacology, vol. 144, no. 1, pp. 57-66, 2012.

[53] A. Sofrata, F. Brito, M. Al-Otaibi, and A. Gustafsson, "Short term clinical effect of active and inactive Salvadora persica miswak on dental plaque and gingivitis," Journal of Ethnopharmacology, vol. 137, no. 3, pp. 1130-1134, 2011. 